\title{
Forage quality and performance of sheep in Massai grass pastures managed at pre-grazing canopy heights
}

\author{
J.V. Emerenciano Neto ${ }^{1 \#}$, G.S. Difante ${ }^{2}$, Â.M.Q. Lana ${ }^{3}$, H.R. Medeiros ${ }^{2}$, \\ E.M. Aguiar ${ }^{2}$, D.B. Montagner ${ }^{4}$ \& J.S. Souza ${ }^{3}$ \\ ${ }^{1}$ Federal University of Vale do São Francisco, Petrolina, Brazil \\ ${ }^{2}$ Federal University of Rio Grande do Norte, Macaíba, Brazil \\ ${ }^{3}$ Federal University of Minas Gerais, Belo Horizonte, Brazil \\ ${ }^{4}$ Brazilian Agricultural Research Corporation, Campo Grande, Brazil
}

(Received 10 April 2017; Accepted 5 August 2018; First published online 20 December 2018)



\begin{abstract}
The objective of this study was to evaluate the effects of pasture height at pre-grazing of Massai grass on the quality of available forage, forage intake and the performance of lambs raised for meat production. The treatments consisted of four pre-grazing canopy heights $(35,40,45$ and $50 \mathrm{~cm}$ ). Pastures were managed by the intermittent stocking method and 32 sheep were used. Dry matter intake (DMI) was estimated by Lipe $₫$ indicator. Green forage allowance was not affected by pre-grazing heights. There was no effect of heights on the chemical composition of the stem or the leaf blades, except for crude protein content of leaf blades, which showed an inverse linear effect. Grazing time had a quadratic response in function of canopy height. The minimum point was at $42.6 \mathrm{~cm}$, with $502.9 \mathrm{~min} /$ day. DMI increased linearly with increasing pasture height. Average daily weight gain (ADG) and stocking rate (SR) responded linearly to pregrazing heights. Weight gain per hectare was not affected by height as a result of the compensation between $\mathrm{SR}$ and ADG. The increase from 35 to $50 \mathrm{~cm}$ in Massai grass canopy height reduces its nutritional value and individual performance and increases DMI of sheep intended for meat production.
\end{abstract}

Keywords: Panicum maximum, tropical pasture, voluntary intake

\#Corresponding author: joao_neto@zootecnista.com.br

\section{Introduction}

Panicum maximum Jacq. cv Massai grass stands out for its high capacity of emitting leaves and tillers, thus being promising for ruminant production systems. According to Fernandes et al. (2014), this forage may be an alternative for sheep production systems in regions with low rainfall, that is, up to $150 \mathrm{~mm}$ distributed over six months. The authors emphasize that there is no compromise of the pasture structure of the Massai grass in these environmental conditions. Nevertheless, studies on the management of this forage in semiarid regions are still scarce (Martuscello et al., 2015). According to Ferro et al. (2015), the great challenge in pasture management is to find the balance between frequency and intensity of grazing in order to achieve greater animal production, in terms of the eco-physiological limits of the plants.

Canopy height is a structural feature that affects animal productivity in pasture, as it has a direct effect on forage mass and biting depth, in addition to altering plant components and grazing dynamics (Pedreira et al., 2009). Therefore, it is of paramount importance to identify pre-grazing canopy heights to optimize forage production (intermittent grazing management), the consumption pattern and the resulting animal performance, as the success of pasture systems is achieved in large part by forage and grazing management.

Pastures managed with fixed rest periods facilitate intermittent stocking management. However, this may compromise gains in system efficiency, resulting in variable structured canopies over time, and thus affecting the pattern of forage intake and animal performance (Pedreira et al., 2009). According to Omondi et al. (2008), sheep are one of the more important livestock species in the semi-arid tropics, with high exploitation potential through sustainable use in order to improve livestock farmers' livelihoods. 
Pasture structure is an important factor in the intake of forage. Among the structural variables of canopy forage, the relations between leaf blade : stem and green material : dead material can be highlighted, as these are associated with ease of access and the demand for more nutritious pasture. Animals have the ability to select leaves and they search for them, even when pasture availability is limited and searching for them demands more time (Bremm et al., 2008).

Under favourable conditions of light, humidity and temperature, pastures are the main food source for ruminants. Understanding their chemical composition and variations over time (crude protein (CP), neutral detergent fibre (NDF), acid detergent fibre (ADF) and in vitro dry matter digestibility (IVDMD)) contributes to identifying factors that may modify nutrient consumption (Vargas Junior et al., 2013).

This study aimed to evaluate the effect of pre-grazing pasture height of Massai grass on the quality of forage available, forage intake and the performance of lambs intended for meat production.

\section{Material and Methods}

The experiment was conducted in the GEFOR (Grupo de Estudos em Forragicultura) experimental area at the Macaíba Campus of the Federal University of Rio Grande do Norte (UFRN) in Macaíba, RN. The experimental area has geographic coordinates of latitude $5^{\circ} 89^{\prime} 25.78^{\prime \prime}$ south and longitude $35^{\circ} 36^{\prime} 37.05^{\prime \prime}$ west, with an average altitude of $50 \mathrm{~m}$ above sea level. The experimental period was from 9 September 2013 to 11 May 2014, amounting to 422 days of evaluation.

The soil of the area is classified as quartzipsamment (EMBRAPA, 2006). Soil fertility analyses (Table 1) were performed by the Brazilian Agricultural Research Corporation of Rio Grande do Norte (EMPARN). The climate, according to the climatic classification of Thornthwaite (1948), is dry, sub-humid with water surplus from May to August. The historical average annual rainfall (for the past 20 years) is $1048 \mathrm{~mm}$ and the cumulative annual average evapotranspiration potential is $1472 \mathrm{~mm}$.

Table 1 Chemical and physical composition of the soil in the experimental area at depths of 0-10 and 10-20 $\mathrm{cm}$ in 2011

\begin{tabular}{|c|c|c|c|c|c|c|c|c|c|c|c|c|c|}
\hline \multirow{2}{*}{$\begin{array}{l}\text { Layers } \\
\text { (cm) }\end{array}$} & $\mathbf{P}$ & K & $\mathrm{Na}$ & & $\mathrm{Ca}$ & Mg & Al & H+Al & \multirow{2}{*}{ CEC } & \multirow{2}{*}{$\begin{array}{l}\text { BS } \\
\text { (\%) }\end{array}$} & \multicolumn{3}{|c|}{ Granulometry (\%) } \\
\hline & \multicolumn{3}{|c|}{$--\left(\mathrm{mg} / \mathrm{dm}^{3}\right)$} & pr & \multicolumn{4}{|c|}{-- $\left(\mathrm{cmol}_{\mathrm{d}} / \mathrm{dm}^{3}\right)$} & & & Sand & Clay & Silt \\
\hline $0-10$ & 4.8 & 92.3 & 20.3 & 6.0 & 1.1 & 0.5 & 0.0 & 1.1 & 29.0 & 63.5 & 84.6 & 4.0 & 11.4 \\
\hline $10-20$ & 2.3 & 81.3 & 16.8 & 5.9 & 0.7 & 0.2 & 0.0 & 1.2 & 23.6 & 49.2 & 85.2 & 2.0 & 12.8 \\
\hline
\end{tabular}

P: phosphor, K: potassium, Na: sodium, Ca: calcium, Mg: magnesium, Al: aluminum, $(\mathrm{H}+\mathrm{Al})$ : potential acidity,

CEC: cation exchange capacity; BS: base saturation

The total assessment area was $9600 \mathrm{~m}^{2}$ (0.96 ha), divided into four equal parts of $2400 \mathrm{~m}^{2}(0.24 \mathrm{ha})$, one for each treatment, and the area designated for each height was divided into six paddocks of $400 \mathrm{~m}^{2}$ (0.04 ha). Treatments consisted of four canopy heights for pre-grazing: 35, 40, 45 and $50 \mathrm{~cm}$. A height of 50 $\mathrm{cm}$ was determined by a correlation with 95\% canopy light interception (Andrade et al., 2006), and the lowest heights were defined to find the balance between the greater frequency of defoliation and the nutritive value of the forage.

Panicum maximum cv. Massai was planted in June 2011, using a conventional seeding system in 20 $\mathrm{cm}$ spaced rows and $\mathrm{P}_{2} \mathrm{O}_{5}$ distribution $(80 \mathrm{~kg} / \mathrm{ha}$ ). Pastures received $150 \mathrm{~kg} / \mathrm{ha}$ of nitrogen $(\mathrm{N})$ annually, always in the rainy season, according to the recommendations of Martuscello et al. (2015). The area was kept permanently free of weed growth, and ant control was conducted throughout the evaluation period. Pastures were irrigated in October, November and December 2013, and in October and November 2014. A sprinkler irrigation system was used with the necessary amount of water to supplement the monthly minimum of $35 \mathrm{~mm}$ to maintain the plant as physiologically active during the restricted rainfall period.

Pastures were managed by intermittent stocking (Allen et al., 2011). The start of the occupation period of each paddock was determined by pre-grazing height set for each treatment, being 12, 14, 15 and 16 days for the heights $35,40,45$ and $50 \mathrm{~cm}$, respectively. Post-grazing height was $15 \mathrm{~cm}$ for all treatments. The pasture rest periods were $73,77,88$ and 87 days for the heights $35,40,45$ and $50 \mathrm{~cm}$, respectively.

Pasture height was determined using a one-meter-ruler graduated in centimetres. Forty points along each paddock were randomly selected and measured. Canopy height at each point corresponded to the average height of the curvature of the leaves, around the ruler (Frame, 1981). 
The forage mass ( $\mathrm{kg} / \mathrm{ha}$ of dry matter (DM)) in the pre- and post-grazing conditions were estimated by a cut close to the ground level contained within the six representative areas of $0.25 \mathrm{~m}^{2}$ in four paddocks of each management system. Subsamples were separated manually into fractions: leaf blade and stem (stem + sheath).

The forage allowance (FA) was calculated by dividing forage mass (FM) available in pre-grazing by the occupation period (OP) added to the accumulation rate (AcR) and divided by stocking rate (SR), expressed in $\mathrm{kg} / \mathrm{ha} \mathrm{DM} / 100 \mathrm{~kg}$ live weight $(\mathrm{LW})$ on each day $(\mathrm{FA}=((\mathrm{FM} / \mathrm{OP})+\mathrm{AcR})) / \mathrm{SR})$, according to the methodology proposed by Sollenberger \& Moore (1997). Accumulation rates were calculated as the difference between the pre- and post-grazing forage mass divided by the number of days of the rest period.

Missing forage mass (MFM) was obtained as the difference between pre-grazing and post-grazing forage mass, and the missing percentage was calculated as the ratio between MFM and pre-grazing mass, multiplied by 100 (Almeida, 1999).

Samples of the morphological components (leaf blade and stem) were pre-dried at $55^{\circ} \mathrm{C}$, ground in a Wiley mill to $1 \mathrm{~mm}$, and subsequently analysed for DM levels, ash, CP, (AOAC, 2000), NDF, ADF and lignin (Van Soest et al., 1991).

Thirty-two 105-day-old castrated male Santa Ines weaned lambs with average live weights of $18.2 \pm$ $2.6 \mathrm{~kg}$ were used for performance evaluation, as well as regulating animals that were placed or removed from the paddocks as needed to adjust the stocking rate for canopy height adjustment (Mott \& Lucas, 1952). The animals entered the experiment after weaning (90 day) and remained until the end of the evaluation, when they were slaughtered. They were kept in the pasture during the day (from 7:00 to 16:00) and sheltered in sheds with collective pens at night, with access to water and mineral salt ad libitum. Containing animals in shelters during this period is a practice that is adopted in most sheep production systems in the north-eastern region of Brazil to prevent predatory attacks and animal theft.

Parasite control was carried out individually each week by monitoring the egg count per gram of faeces according to the methodology described by Gordon \& Whitlock (1939). An anthelmintic oral application was performed whenever it reached 500. Animals were weighed weekly and total weight gain was calculated as the difference in animal weight at the beginning and end of the trial period. Average daily gain (ADG) (g/day) was calculated as the total gain divided by grazing days. Weight gain per hectare was obtained by multiplying the stocking rate and the ADG (g/day/ha).

Evaluations of the consumption pattern were conducted every three months, when observations were made in 24-hour shifts and the animals' activities were recorded every five minutes. The animals were evaluated visually for feeding behaviour, with three test animals for each observer. Biting rate was calculated from the time required for animals to perform 20 bites, then transformed into bites per minute (Hodgson, 1985). The observed activities were grazing, rumination and idle times, with the last two divided into standing and lying down. All observations for the day were added up for each variable and expressed in $\mathrm{min} /$ day.

Daily faecal production (FP) was estimated by faecal output using a Lipe marker, and $250 \mathrm{mg}$ capsules were introduced orally to the animals (six per canopy height every three months) for seven days, in which daily collection of animal faeces was conducted for five days after the first two days of application. After all samples had been collected, the stools were frozen and a pool of five faecal samples for each animal was prepared and dehydrated in a circulation oven set at $55^{\circ} \mathrm{C}$ until constant weight. After drying, the samples were ground to $1 \mathrm{~mm}$ and forwarded to the Simoes and Saliba laboratory to determine the Lipe ${ }^{\circledR}$ faeces concentration by infrared spectroscopy (Saliba et al., 2015).

The IVDMD was determined according to the methodology of Tilley \& Terry (1963). To estimate dry matter intake (DMI), the following formula was used:

$$
\text { DMI }(\% B W)=(F P(k g / \text { day }) /(1-I V D M D(k g / k g)) / l i v e \text { weight } \times 100 \text { (Penning \& Johnson, 1983). }
$$

The animals were slaughtered according to the Technical Regulations of Desensitization Methods for Humanitarian Animal Slaughtering (IN N ${ }^{\circ}$ 3-MAPA, 2000) and in accordance with the authorization of the Ethics Committee for Animal Use (CEUA-UFRN, Protocol no. 022/2015). The animals were subjected to solid fasting for 16 hours before being slaughtered. After this period they were weighed again to obtain fasting weight (FW) and fasting loss. After skinning, the head and the extremities of the lambs were removed. The hot carcass weight $(\mathrm{HCW})$ was recorded to estimate hot carcass yield ( $\mathrm{HCY})$ :

$$
\mathrm{HCY}=\mathrm{HCW} / \mathrm{FW} \times 100
$$

The animals were slaughtered with a live weight of at least $28 \mathrm{~kg}$, which is the ideal weight for lamb slaughter, according to Siqueira et al. (2001). 
The adopted design was completely randomized. The data were submitted to variance analysis and the effect of heights was assessed using regression analysis at $5 \%$ significance. The following model was used:

$$
Y_{i j k}=\mu+A_{i}+\alpha_{i j}
$$

where: $Y_{i j k}=$ value observed at $\mathrm{i}$ height, repetition (animal or paddock) $\mathrm{j}$

$\mu=$ overall average effect

$A_{i}=$ height effect $i, i=35,40,45$ and $50 \mathrm{~cm}$

$a_{i j}=$ effect of random error attributed to repetition

\section{Results}

Leaf blade and stem allowance (on offer) were not affected by canopy heights pre-grazing $(P>0.05)$. The average values were 23.3 and $11.1 \mathrm{~kg} \mathrm{DM} / 100 \mathrm{~kg}$ of live green forage weight, respectively (Table 2). The ratio between leaf blade mass and stem mass were not modified by pre-grazing canopy heights $(P$ $>0.05$ ). Thus, the result was positive because leaf blade mass was approximately 2.5 times higher on average than stem mass. Declining leaf blade and stem mass and their declining percentage during occupation had linear responses to canopy heights $(P<0.05)$.

Table 2 Massai grass pasture variables managed under pre-grazing canopy heights and occupied by sheep

\begin{tabular}{|c|c|c|c|c|c|c|c|c|}
\hline \multirow{2}{*}{ Variable } & \multicolumn{4}{|c|}{ Canopy height (cm) } & \multirow{2}{*}{ Mean } & \multirow{2}{*}{ SEM } & \multicolumn{2}{|c|}{ Significance $^{1}$} \\
\hline & 35 & 40 & 45 & 50 & & & Linear & Quadratic \\
\hline Leaf blade allowance ( $\mathrm{kg} \mathrm{DM/100} \mathrm{kg} \mathrm{LW)}$ & 22.2 & 23.1 & 24.7 & 23.2 & 23.3 & 3.8 & NS & NS \\
\hline Stem allowance (kg DM/100 kg LW) & 10.9 & 10.6 & 12.8 & 9.6 & 11.0 & 2.0 & NS & NS \\
\hline Leaf blade : stem ratio & 2.5 & 2.5 & 2.2 & 2.4 & 2.4 & 0.2 & ** & NS \\
\hline Leaf blade disappearance (kg/ha DM) & 1776 & 2498 & 2188 & 3051 & 2378 & 220 & ** & NS \\
\hline Stem disappearance (kg/ha DM) & 116 & 293 & 444 & 529 & 346 & 105.8 & ** & NS \\
\hline Leaf blade disappearance (\%) & 80.1 & 87.8 & 84.4 & 92.2 & 86.1 & 3.9 & * & NS \\
\hline Stem disappearance (\%) & 8.3 & 15.9 & 35.5 & 36.7 & 24.1 & 9.6 & * & NS \\
\hline
\end{tabular}

${ }^{1}$ NS (not significant), $P>0.05 ; * P<0.05 ;{ }^{\star *} P<0.01$.

DM: dry matter; LW: live weight

Canopy height had no effect on pre-grazing in the chemical composition and IVDMD of leaf blades (Table 3), except for CP content $(P<0.05)$, which showed an inverse linear effect according to the equation:

Crude protein in the leaf blade $=12.73-0.126 \times\left(R^{2}=65.17\right)$,

where: $x=$ pre-grazing height.

Chemical composition and IVDMD of the stem were not affected by pre-grazing heights $(P>0.05)$. Voluntary DMI increased linearly (Table 4$)$ with increasing pasture height $(P<0.05)$, with the highest estimated value being $2.0 \%$ of LW. Biting rate of animals had a linear response to canopy heights $(P<0.05)$, where there was a decrease in BR with increased pasture height. Grazing time and idling time have quadratic response according to the canopy heights $(P<0.05)$. The estimated height where the animals had the lowest grazing time was $42.6 \mathrm{~cm}$ with grazing time of $502.9 \mathrm{~min} /$ day, while the estimated height where the animals had more idling time was $42.1 \mathrm{~cm}$ with the time of $519.9 \mathrm{~min} /$ day. Ruminating time was not affected by the forage canopy height $(P>0.05)$. 
Table 3 Average chemical composition attributes of the morphological components of Massai grass for the four canopy heights in pre-grazing

\begin{tabular}{|c|c|c|c|c|c|c|c|c|}
\hline \multirow{2}{*}{ (g/kg DM) } & \multicolumn{4}{|c|}{ Canopy height (cm) } & \multirow{2}{*}{ Mean } & \multirow{2}{*}{ SEM } & \multicolumn{2}{|c|}{ Significance $^{1}$} \\
\hline & 35 & 40 & 45 & 50 & & & Linear & Quadratic \\
\hline \multicolumn{9}{|c|}{ Stem } \\
\hline Mineral matter & 71 & 62 & 61 & 58 & 63 & 06 & NS & NS \\
\hline Crude protein & 54 & 44 & 49 & 34 & 45 & 13 & NS & NS \\
\hline Neutral detergent fibre & 797 & 816 & 782 & 813 & 802 & 29 & NS & NS \\
\hline Acid detergent fibre & 607 & 639 & 620 & 602 & 617 & 09 & NS & NS \\
\hline Lignin & 92 & 101 & 95 & 102 & 96 & 05 & NS & NS \\
\hline In vitro dry matter digestibility & 445 & 422 & 435 & 448 & 438 & 15 & NS & NS \\
\hline \multicolumn{9}{|c|}{ Leaf blade } \\
\hline Mineral matter & 97 & 95 & 85 & 88 & 91 & 09 & NS & NS \\
\hline Crude protein & 79 & 79 & 80 & 57 & 74 & 18 & * & NS \\
\hline Neutral detergent fibre & 723 & 736 & 733 & 724 & 729 & 11 & NS & NS \\
\hline Acid detergent fibre & 539 & 558 & 528 & 560 & 546 & 13 & NS & NS \\
\hline Lignin & 62 & 72 & 60 & 73 & 65 & 08 & NS & NS \\
\hline In vitro dry matter digestibility & 493 & 480 & 501 & 478 & 488 & 09 & NS & NS \\
\hline
\end{tabular}

${ }_{*}^{1} \mathrm{NS}$ (not significant), $P>0.05$;

$P<0.05$

Table 4 Dry matter intake, grazing time, biting rate, ruminating time and idle time of sheep in Massai grass pasture managed with pre-grazing canopy heights

\begin{tabular}{|c|c|c|c|c|c|c|c|c|}
\hline & \multicolumn{4}{|c|}{ Canopy height (cm) } & \multirow{2}{*}{ Mean } & \multirow{2}{*}{ SEM } & \multicolumn{2}{|c|}{ Significance $^{1}$} \\
\hline & 35 & 40 & 45 & 50 & & & Linear & Quadratic \\
\hline Dry matter intake (\% LW) & 1.7 & 1.6 & 2.0 & 2.0 & 1.8 & 0.1 & ** & NS \\
\hline Dry matter intake $\left(\mathrm{g} / \mathrm{LW}^{0.75}\right)$ & 39.1 & 37.8 & 44.8 & 44.3 & 41.5 & 1.6 & $\star *$ & NS \\
\hline Grazing time (min/day) & 517.5 & 499.4 & 478.9 & 543.1 & 509.7 & 3.8 & $* *$ & 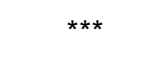 \\
\hline Biting rate (bit/min) & 35.0 & 28.1 & 32.6 & 26.0 & 30.4 & 1.1 & NS & * \\
\hline Rumination time (min/day) & 481.7 & 462.2 & 432.8 & 472.2 & 462.2 & 16.1 & NS & NS \\
\hline Idle time (min/day) & 456.4 & 486.7 & 534.7 & 423.6 & 475.3 & 18.2 & NS & *** \\
\hline
\end{tabular}

LW: live weight

The ADG of the lambs in the study had a linear decline as a function of increasing pre-grazing heights (Table 5), which decreased from the smallest to the largest grazing heights. Stocking rate was adjusted by a linear regression model based on pre-grazing height $(P<0.05)$. Weight gain per hectare was not influenced by pre-grazing height $(P>0.05)$; at the lower heights, the greater ADG compensated for the lower stocking rate. Final weight and the total gain per animal responded linearly to pre-grazing heights $(P<0.05)$, with both decreasing with increasing pasture heights in pre-grazing (Table 5). Hot carcass weight (Table 5) responded inversely to the linear function of pre-grazing heights $(P<0.05)$. Hot carcass yield was not changed by pregrazing heights $(P>0.05)$, with an average yield of $40.3 \%$. 
Table 5 Average daily weight gain, stocking rate, gain per area, total gain, final weight, hot carcass weight and hot carcass yield of sheep in Massai grass pasture managed at pre-grazing heights

\begin{tabular}{|c|c|c|c|c|c|c|c|c|}
\hline & \multicolumn{4}{|c|}{ Canopy height (cm) } & \multirow{2}{*}{ Mean } & \multirow{2}{*}{ SEM } & \multicolumn{2}{|c|}{ Significance $^{2}$} \\
\hline & 35 & 40 & 45 & 50 & & & Linear & Quadratic \\
\hline Stocking rate $(\mathrm{AU} / \mathrm{ha})^{1}$ & 27.0 & 28.1 & 32.6 & 35.6 & 30.8 & 1.9 & ** & NS \\
\hline Average daily gain (g/day) & 41.6 & 25.0 & 23.7 & 20.8 & 27.8 & 3.4 & $\star \star$ & NS \\
\hline Gain per area (g/day.ha) & 1350 & 1246 & 1186 & 1286 & 1267 & 111.9 & NS & NS \\
\hline Total gain per animal $(\mathrm{kg})$ & 15.8 & 9.5 & 9.0 & 7.9 & 10.5 & 1.5 & * & NS \\
\hline Final weight (kg) & 35.5 & 31.4 & 31.8 & 31.2 & 32.5 & 1.2 & * & NS \\
\hline Hot carcass weight $(\mathrm{kg})$ & 14.0 & 11.8 & 12.9 & 11.1 & 12.4 & 0.6 & * & NS \\
\hline Hot carcass yield (\%) & 41.4 & 39.3 & 42.6 & 38.0 & 40.3 & 1.3 & NS & NS \\
\hline
\end{tabular}

${ }^{1} \mathrm{AU}$ : animal unit of $30 \mathrm{~kg}$; NS (not significant), $P>0.05 ;{ }^{*} P<0.05 ;{ }^{* \star} P<0.01$

\section{Discussion}

Leaf blade and stem differences of the material on offer may be explained because of the required capacity adjustment performed to maintain the management targets. According to Gómez et al. (2010), there is reduced weight gain in animals in an intermittent stocking system with a forage allowance above $2 \mathrm{~kg}$ $\mathrm{DM} / 100 \mathrm{~kg}$ LW due to the excessive accumulation of forage, especially stems and senescent material, which depreciates its quality.

Greater dry matter disappearance is due to the higher stratum potentially consumed by the animals, meaning the greater the amplitude between pre- and post-grazing height targets. High percentages in missing leaf blades demonstrate high harvesting efficiency in both evaluated targets, but we should consider that the higher the percentage of leaves removed by lower grazing will reduce the residual leaf area postgrazing, and thereby depress the conditions for pasture regrowth.

Even at the lowest height, CP levels in leaf blades were lower than the $97 \mathrm{~g} / \mathrm{kg}$ DM reported by Emerenciano Neto et al. (2014) for Massai grass managed at $50 \mathrm{~cm}$ in pre-grazing using the same fertilization application (150 kg/ha of nitrogen per year). This is associated with two factors: the plant's age (Fernandes et al., 2014), as the results described by the authors were obtained in the first year of forage use, while the evaluations in this study were in the third year after planting; and the rest period time, which was higher in this study, and may have caused increased maturity of the plant tissues.

Changes in pasture chemical composition are often attributed to excessive stem elongation due to the increase in participating structural components and reduced cell content. However, Massai grass has a low stem elongation rate (Lopes et al., 2013; Luna et al., 2014; Martuscello et al., 2015), and a difference of 14 days in the sprouting stage from the lowest to highest height was not sufficient to cause structural changes in the stem, or consequently on the chemical composition. The low nutritional quality of the pasture components is compensated by the quantity of forage produced (Table 2), which justifies the recommendation of Massai grass as a cultivation option for low precipitation regions. Animal production is limited in these regions by the supply of bulk food, while diet quality can be improved by the use of concentrated supplements (Moreira et al., 2007).

Even when the highest DMI was found to be low (2.0\% of LW), high levels of NDF and ADF limit consumption due to the low digestibility and lower feed passage rate, which physically limit DM intake. According to Figueiredo et al. (2013), an alternative for increasing consumption of diets exclusively containing forage would be to supply concentrate to the animals, which can reduce the grazing time in increasing levels (Bremm et al., 2008).

This quadratic response to biting rate may be related to animals' compensatory grazing behaviour to maintain their DMI (Amaral et al., 2012). When there is greater available forage mass, biting mass tends to be larger and the animals need more time to manipulate this mass in their mouths, which reduces the biting rate. At lower grazing heights, less forage mass is available to the animal and consequently biting mass is reduced, thus requiring more grazing time. Conversely, greater herbage mass requires more jaw movements per bite (Mezzalira et al., 2014), causing grazing time to be greater. This behaviour was also observed by Mezzalira et al. (2014) in Cynodon cattle grazing managed under pre-grazing heights.

The grazing time results may be related to the biting rate and bite mass. The highest biting rate was estimated at the height of $35 \mathrm{~cm}$, which can be related to lower bite mass and thus resulting in more bites 
and more time to ensure ingestion; whereas in the pasture height of $50 \mathrm{~cm}$, the mass of each mouthful is probably bigger and demands more time for manipulating (prehending and chewing) in the animals' mouths.

The ruminating time was not affected by canopy height $(P>0.05)$. Rumination time is highly correlated to the NDF intake. According to Van Soest (1994), an increase in NDF promotes increased rumination time owing to the increased need for crushing the fibre. As there was no change in the NDF of the pastures, the rumination time showed no significant differences between heights. Idle time is a reflection of other activities. This behaviour is the opposite of grazing time (Table 4), meaning that when more time was spent grazing, idle time decreased. According to Ribeiro et al. (2014), animals have compensatory food strategies in situations where there is reduced availability and quality of forage, prioritizing grazing time to maintain forage intake.

The higher intake of DM observed in the animals kept on the pastures managed at the higher pregrazing canopy heights resulted in lower ADGs. This result can be explained by the values of forage disappearance at the higher canopy heights where there was a greater disappearance of stems compared to leaf blades (Table 2), which infers that there was greater contribution of this lower quality component (Table 3 ) in the ingested forage, which resulted in the lower performance of the animals. Even the highest ADG observed in this study (37.3 g/day) was lower than that described by Emerenciano Neto et al. (2014) for Santa Ines sheep in Massai grass pastures managed with post-grazing height of $25 \mathrm{~cm}$ during the rainy season (49.2 g/day). The lower performance is a function of the greater grazing intensity (post-grazing height of $15 \mathrm{~cm}$ ) and by the lower nutritional quality of the pasture. The observed ADG values were also lower than the $61 \mathrm{~g} /$ day described by Silva et al. (2014), obtained for 4-year-old adult sheep in the finishing phase and in a Massai grass pasture with higher nutritional value ( $140 \mathrm{~g} / \mathrm{kg}$ of $C P$ and $34.2 \mathrm{~g} / \mathrm{kg}$ of ADF).

To maintain pasture management targets, an additional 9.03 animal units (AU) $(30 \mathrm{~kg}) / \mathrm{ha}$ was needed to manage the $50 \mathrm{~cm}$ compared with $35 \mathrm{~cm}$ grazing height. The results of final weight and the total weight gain per animal are explained by the lower ADG. More time is needed for animals to reach the slaughter weight required by the market at the highest pre-grazing management heights, hence the animal remains in the production system longer, which can lead to higher costs and increased seasonal risks in the pasture allowance before slaughter.

The hot carcass weight is of great importance because it is the basis for payment to producers. Thus, pasture management at $35 \mathrm{~cm}$ pre-grazing height promotes higher revenue per animal. Variation in pregrazing pasture heights was not sufficient to cause large enough variations in nutritional forage to modify the HCY. The hot carcass yield obtained was close to that observed by Garcia et al. (2010) for pure and crossed Santa Ines sheep only in Aruana grass pasture (41.9\%), while the group that received supplementation had higher hot carcass yield. The authors attribute this result to the diet having a greater allowance of nutrients, and thus greater development of the main parts that compose the carcass (muscle, bone and fat) compared to other parts of the body.

Massai grass pastures produce enough forage mass to maintain about $30.8 \mathrm{AU} / \mathrm{ha}$, and a reasonable nutritional value, sufficient to provide gains of $27.8 \mathrm{~g} /$ day. Considering the low nutritional value of Massai grass, protein and energy supplementation is required to optimize lamb performance.

\section{Conclusions}

Increased Massai grass pre-grazing height causes a reduction in nutritional value and is reflected by lower individual performance. However, it does not compromise productivity per area due to increased stocking rate. Defining pre-grazing Massai grass height should be based on the production system's objectives, namely $35 \mathrm{~cm}$ to optimize individual gain and $50 \mathrm{~cm}$ to optimize stocking rate.

\section{Acknowledgements}

To CNPq and PROCAD/CAPES for financial support for developing the study and the scholarship granted to the first author. To the GEFOR (Grupo de Estudos em Forragicultura -UFRN) for the assistance in executing this study. This study was financed in part by the Coordenação de Aperfeiçoamento de Pessoal de Nível Superior - Brasil (CAPES) Finance Code 001".

\section{Authors' Contributions}

Concept and design: JVEN, GSD and AMQL; data collection and analysis: JVEN and JSS; laboratory analysis: HRM and EMA; drafting of paper: JVEN; critical revision and final approval of version to be published: GSD and DBM. This statement is to certify that all the authors of this paper made substantial contributions to conception and design, and/or acquisition of data, and/or analysis and interpretation of data. All the authors have seen and approved the manuscript being submitted. All authors have seen and approved the manuscript being submitted. We guarantee that the article is the authors' original work and has not received prior publication and is not under consideration for publication elsewhere. 


\section{Conflict of Interest Declaration}

The authors certify that they have no affiliations with any organisation or entity with any financial or non-financial interest in the subject matter or materials discussed in this manuscript.

\section{References}

Allen, V.G., Batello, C., Berretta, E.J., Hodgson, J., Kothmann, M., Li, X., Mclvor, J., Milne, J., Morris, C., Peeters, A. \& Sanderson, M., 2011. An international terminology for grazing lands and grazing animals. Grass Forage Sci. 66, 2-28.

Almeida, M.S., 1999. Agronomical methods to estimate pasture voluntary intake. Arq. Ciênc. Vet. Zool. UNIPAR 2, 61-70.

Amaral, M.F., Mezzalira, J.C., Bremm, C., Trindade, J.K., Gibb, M.J., Sun, R.W.M. \& Carvalho, P.C.F., 2012. Sward structure management for a maximum short-term intake rate in annual ryegrass. Grass Forage Sci. 68, $271-277$.

Andrade, C.M.S., Garcia, R., Valentim, J.F. \& Pereira, O.G., 2006. Grazing management strategies for massaigrassforage peanut pastures: 3. Definition of sward targets and carrying capacity. R. Bras. Zootec. 35, 352-357.

AOAC, 2000. Association of Official Analytical Chemists. Official methods of analysis. 17th edition. Washington, DC., USA.

Bremm, C., Silva, J.H.S., Rocha, M.G., Elejalde, D.A.G., Oliveira Neto, R.A. \& Confortin, A.C.C., 2008. Ingestive behavior of ewes and ewe lambs on Italian ryegrass pasture under increasing supplement levels. R. Bras. Zootec. 37, 97-106.

Emerenciano Neto, J.V., Difante, G.S., Montagner, D.B., Bezerra, M.G., Galvão, R.C.P. \& Vasconcelos, R.I.G., 2013. Sward structural characteristics and herbage accumulation in tropical grasses, under intermittent stocking and sheep grazed. Biosci. J. 29, 962-973.

Emerenciano Neto, J.V., Difante, G.S., Aguiar, E.M., Fernandes, L.S., Oliveira, H.C.B. \& Silva, M.G.T., 2014. Performance of meat sheep: Chemical composition and structure of tropical pasture grasses managed under intermittent capacity. Biosci. J. 30, 834-842.

Empresa Brasileira de Pesquisa Agropecuária - EMBRAPA Sistema brasileiro de classificação de solos., 2006. 2nd edition. Rio de Janeiro, $306 \mathrm{p}$

Fernandes, F.D., Ramos, A.K.B., Jank, L., Carvalho, M.A., Martha Junior, G.B. \& Braga, G.J., 2014. Forage yield and nutritive value of Panicum maximum genotypes in the Brazilian savannah. Sci. Agric. 71, 23-29.

Ferro, M.M., Zanine, A.M., Ferreira, D.J., Souza, A.L. \& Geronand, L.J.V., 2015. Organic reserves in tropical grasses under grazing. Am. J. Plant Sci. 6, 2329-2338.

Figueiredo, M.R.P., Saliba, E.O.S., Borges, I., Rebouças, G.M.N., Silva, F.A. \& Sá, H.C.M., 2013. Ingestive behavior of sheep fed with different sources of fiber. Arq. Bras. Med. Vet. Zootec. 65, 485-489.

Frame, J., 1981. Herbage mass. In: J. Hodgson, R.D Baker, A. Davies, A.S. Laidlaw \& J.D. Leaver (eds). Sward Measurement Handbook. British Grassland Society, Berkshire. pp. 39-67.

Garcia, I.F.F., Costa, T.I.R., Almeida, A.K., Pereira, I.G., Alvarenga. F.A.P. \& Lima, N.L.L., 2010. Performance and carcass characteristics of Santa Inês pure lambs and crosses with Dorper e Texel at different management systems. R. Bras. Zootec. 39, 1313-1321.

Gómez, J.M.D., Fischer, V., Poli, C.H.E.C., Carvalho, P.C.F., Pegoraro, E.J. \& Macari, S., 2010. Effect of forage supply, methods of grazing, evaluation days and breed on the behavior and the temperament of sheep. R. Bras. Zootec. 39, 1840-1848.

Gordon, H.M.C.L. \& Whitlock, H.V., 1939. A new technique for counting nematode eggs in sheep faeces. J. Sci. Ind. Res. 12, 50-52.

Hodgson, J., 1985. The control of herbage intake in the grazing ruminant. Proc. Nutr. Soc. 44, 339-346.

Lopes, M.N., Cândido, M.J.D., Pompeu, R.C.F.F., Silva, R.G., Carvalho, T.C.F., Sombra, W.A., Morais, Neto L.B. \& Peixoto, M.J.A., 2013. Biomass flow in Massai grass fertilized with nitrogen under intermittent stocking grazing with sheep. R. Bras. Zootec. 42, 13-21.

Luna, A.A., Difante, G.S., Montagner, D.B., Emerenciano Neto, J.V., Araújo, I.M.M. \& Oliveira, L.E.C., 2014. Accumulation of forage and morphogenic responses in forage grass by cutting. Biosci. J. 30, 1803-1810.

Martuscello, J.A., Silva, L.P., Cunha, D.N.F.V., Batista, A.C.S., Braz, T.G.S. \& Ferreira, P.S., 2015. Nitrogen fertilization in Massai grass: Production and morphogenesis. Cienc. Anim. Bras. 16, 1-13.

Mezzalira, J.C., Carvalho, P.C.F., Fonseca, L., Bremm, C., Cangiano, C., Gonda, H.L. \& Laca, E.A., 2014. Behavioural mechanisms of intake rate by heifers grazing swards of contrasting structures. Appl. Anim. Behav. Sci. 153, 1-9.

Moreira, J.N., Lira, M.A., Santos, M.V.F., Araújo, G.G.L. \& Silva, G.C., 2007. Potential production of buffel grass during the dry season in the semi-arid of Pernambuco. Rev. Caatinga 20, 20-27.

Mott, G.O. \& Lucas, H.L., 1952. The design, conduct, and interpretation of grazing trials on cultivated and improve pastures. In: International Grassland Congress, 6, 1952, Pensylvania. Proceedings, Pensilvania. pp.1380-1385.

Omondi, I., Baltenweck, I., Drucker, A.G., Obare, G. \& Zander, K.K., 2008. Economic valuation of sheep genetic resources: implications for sustainable utilization in the Kenyan semi-arid tropics. Trop. Anim. Health Prod. 40, 615-626.

Pedreira, B.C., Pedreira, C.G.S. \& Silva, S.C., 2009. Herbage accumulation during regrowth of Xaraés palisade grass submitted to rotational stocking strategies. R. Bras. Zootec. 38, 618-625.

Penning, P.D. \& Johnson, R.H., 1983. The use of internal markers to estimate herbage digestibility and intake: 2. Indigestible acid detergent fibre. J. Agric. Sci. 100, 133-138. 
Ribeiro, T.M.D., Monteiro, A.L.G., Piazzetta, H.L., Carvalho, P.C.F., Silva, M.G.B., Silva, C.J.A., Natel, A.S., Souza, D.F. \& Meirelles, P.R.L., 2014. Ingestive behavior of lambs in production systems on Italian ryegrass. Vet. e Zootec. 21, 117-126.

Saliba, E.O., Faria, E.P., Rodriguez, N.M., Moreira, G.R., Sampaio, I.B.M., Saliba, J.S., Gonçalves, L.C., Borges, I. \& Borges, A.L.C.C., 2015. Use of infrared spectroscopy to estimate fecal output with marker Lipe®. Int. J. Food Sci. Nutr. Diet. 4, 1-10.

Silva, F.V., Carvalho, Z.G., Sá, H.C.M., Oliveira, L.L.S., Alves, D.D., Silva, V.L., Soares, F.D.S. \& Santos, C.C.R., 2014. Weight gain, carcass and meat traits of ewes finished on pasture with different levels supplementation. Rev. Bras. Saúde Prod. Anim. 15, 206-220.

Siqueira, E.R., Simões, C.D. \& Fernandes, S., 2001. Sex and slaughter weight effects on meat production of lambs. Carcass morphometric evaluation, cuts weights, tissues and offal percentages. R. Bras. Zootec. 30, 1299-1307.

Sollenberger, L.E. \& Moore, J.E., 1997. Assessing forage allowance-animal performance relationships on grazed pasture. Agron. Abstr. 140-141.

Tilley, J.M.A. \& Terry, R.A., 1963. A two-stage technique for the in vitro digestion of forage crops. J. Br. Grassl. Soc. I8, 104-111.

Thornthwaite, C.W., 1948. An approach toward a rational classification of climate. Geog. Rev. 38, 55-94.

Van Soest, P.J., Robertson, J.D. \& Lewis, B.A., 1991. Methods for dietary fiber, neutral detergent fiber, nonstarch polysaccharides in relation to animal nutrition. J. Dairy Sci. 74, 3583-3597.

Van Soest, P.J., 1994. Nutritional Ecology of the Ruminant. 2nd edition. Cornell University Press, Ithaca NY. 476 p.

Vargas Junior, F.M., Socorro, M.M., Setti, J.C.A., Pinto, G.S., Martins, C.F., Costa, J.A.A., Magrin, M.N., Camilo, F.R. \& Montagner, D.B., 2013. Productivity and nutritive value of tropical grasses subjected to grazing with sheep. Arch. Zootec. 62, 295-298. 